\title{
A Chosen Missionary People? Willibrord, Boniface, and the Election of the Angli
}

\author{
Miriam Adan Jones*
}

Abstract: In the seventh and eighth centuries, missionaries from Anglo-Saxon England travelled to the continent with the aim of spreading the gospel among its Germanic peoples. This movement has been seen as a response to a sense of collective vocation tied to the belief that the English were God's chosen people. This article combs sources associated with the circles of the missionaries Willibrord (d. 739) and Boniface (d. 754) for evidence of such a belief. It breaks down the concept of ethnic election with a missionary purpose into its separate components to be analysed in turn. In the first section, it is argued that Anglo-Saxon missionaries saw themselves as belonging to the Angli, a people united by faith, homeland, and bonds of kinship. The second section presents evidence that the missionaries viewed their own people and its church as specially favoured by God; this favour was tied to the maintenance high standards of belief and practice. The final section considers whether this sense of election acted as a motivator for Anglo-Saxon missionary efforts. It concludes that, despite subsequent claims to the contrary by their contemporaries and successors, the missionaries themselves did not specifically connect the special status of their people with the purpose of evangelism.

Keywords: Anglo-Saxons; mission; Willibrord; Boniface; ethnicity; divine election

\section{Introduction}

Late in the eighth century, Alcuin (c. 735-804), scholar, poet and educator at Charlemagne's courts, wrote a poem extolling the virtues of his native Northumbria. Although his interest was primarily local, at one point his focus expands to the English people more generally, and their role in the conversion of the peoples of the continent:

This race of ours, mother of famous men,

did not keep her children for herself, (...)

but sent many of them afar across the seas,

bearing the seeds of life to other peoples. ${ }^{1}$

The following verses outline the efforts of missionaries to Frisia and Saxony in the late seventh and early eighth centuries. Alcuin's words suggest that the missions were something of a national project, a suggestion that is echoed in the work of modern scholars who view the work of Anglo-Saxon missionaries as the extension of a widely shared English preoccupation

* Correspondence Details: Miriam Adan Jones, Faculty of Theology, VU University, De Boelelaan 1105, 1181 HV Amsterdam, The Netherlands, email: m.a.adan@vu.nl

1 Nec gens clarorum genetrix haec nostra virorum,/ quos genuit soli sibimet tunc ipsa tenebat, ... sed procul ex illis multos trans aequora misit,/ gentibus ut reliquis praeferrent semina vitae. Alcuin, Versus de patribus, regibus et sanctis Eboracensis ecclesiae ll. 1008-1009, 1011-1012, ed./trans. Godman, 82-83. 
with continental mission, which was seen as "a national undertaking of the whole English people. $\aleph^{2}$ More specifically, the missionaries' decision to engage in the work of evangelism has sometimes been understood as being based on their belief that the Anglo-Saxons had been divinely chosen and called to advance the gospel to the ends of the earth. ${ }^{3}$

The argument for this position does not usually begin with the missionaries themselves, but with the Northumbrian monk and prolific author Bede (672/3-735). Reading his Ecclesiastical History of the English People as a historiographical exploration of what it means to be the English people of God, many scholars conclude that he believed the English people had been divinely chosen and called. ${ }^{4}$ That missionary activity was essential to this national identity as a chosen people, is supported by two lines of reasoning. First, Bede contrasts the English with the Britons, who had in the past been the recipients of special divine favour, but had lost that favour - and with it their control of Britain - because of their wickedness. ${ }^{5}$ Bede reckoned the Britons' failure to evangelize the Anglo-Saxons who came to inhabit Britain with them as one of their most grievous sins. ${ }^{6}$ He thus implies that divine election comes with a missionary responsibility. Second, an account of the early Anglo-Saxon missions forms a major component of the concluding part of Bede's narrative, so that the arc of English history as divinely ordained included and culminated in bringing the gospel to other peoples. ${ }^{7}$ The popularity of Bede's work among his near contemporaries suggests that his narrative struck a chord, which in turn indicates that his ideas about the English as a chosen missionary people were more widely shared. ${ }^{8}$ The efforts of Anglo-Saxon missionaries can thus be interpreted through the framework provided by Bede: Nicholas Howe, for instance, has argued Boniface's missionary activities provided the practical counterpoint to Bede's theoretical argument for the election of the English and their "destiny as a missionary people. «"

However, this interpretation of Bede has been challenged. Sarah Foot, though convinced that Bede saw the English as "specially chosen and beloved by God", denies that their special status is linked in his mind to the Christianization of continental pagans. ${ }^{10}$ She argues that Bede considered the mission of the church complete with the conversion of the British Isles, since the faith had now reached the farthest corners of the world. ${ }^{11}$ Going one step further, George Molyneaux has recently challenged the idea that Bede presented the Angli as and promoting the idea of the English people, including a vision of the English as divinely chosen: Wormald, Venerable Bede, esp. 213-218 and 224-227; Wormald, Bede, the Bretwaldas and the Origins; Wormald, Engla Lond. See also Howe, Migration and Mythmaking, 49-71; Howe, Writing the Map, 50; Foot, Making of Angelcynn; Smith, Chosen Peoples, 116-117, 144-145; Harris, Race and Ethnicity, 45-51; Scheil, Footsteps of Israel, 106-109; Zacher, Rewriting the Old Testament, 25-28; Wood, Who Are the Philistines?

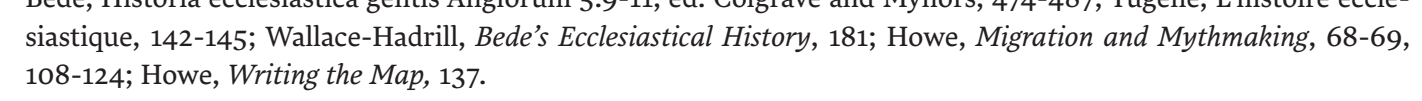

8 Hastings, Construction of Nationhood, 39.

9 Howe, Migration and Mythmaking, 125.

10 Foot, Bede's Church, 16.

11 Foot, Bede's Church, 10-11. 
a chosen people at all. ${ }^{12}$ Challenges such as these have shaken the Bedan foundations under the idea that the English missions of the seventh and eighth centuries were the result of an Anglo-Saxon myth of ethnic election.

This article seeks to open up a new angle on the questions whether the Anglo-Saxons considered themselves God's elect, and whether such a belief can have contributed to their missionary drive, by setting Bede aside and focusing on the missionaries themselves. It concentrates on the circles of Willibrord (658-739) and Boniface (c. 675-754). Willibrord was a Northumbrian, educated at York and in Ireland, who set out to missionize the pagans of Frisia in the 690s; Boniface, born Winfrith, a West-Saxon who first worked alongside Willibrord (719-721) and later headed his own missionary efforts in Hesse and Thuringia, in addition to acting, from 738 , as papal legate to the Frankish church. I argue that, on the one hand, these missionaries viewed the English people, united by their common descent, homeland, and faith, as divinely favoured in a special way, and therefore called to uphold high standards of belief and practice. On the other hand, however, that favour is not unequivocally claimed as exclusive to the English, nor is it explicitly connected to the missionaries' work of conversion.

Anthony Smith has described a myth of ethnic election as a widely shared belief that a people is chosen and set apart to stand in special relation to God and to fulfil a special role in providential history. His work identifies two models of ethnic election, the covenantal and the missionary, though the latter model presupposes and extends the former. ${ }^{13}$ Chosen peoples are marked by the receipt of a divine promise, a calling to live by a sacred law and collectively uphold a high standard of truth and morality, and, in the case of the missionary type, to transform the world around them according to God's will. If they fulfil their calling, they are rewarded with divine favour; if they fail to do so, they are punished by the withdrawal of that favour. ${ }^{14}$ While unmistakable claims to be a chosen people in the sense described by Smith were made by several nations in the modern era, attempts to trace the roots of these claims back to the Middle Ages are fraught with difficulty. Focusing on the Franks, Mary Garrison has problematized and historicized early medieval notions of ethnic election, showing that Frankish claims to be a new chosen people were the product of contested and protracted developments. ${ }^{15}$ Ethnic election as a concept is difficult to trace in part because it is tangled up with broader notions of the church as a whole as the elect people, a theme that finds its origins in the New Testament and reverberates through the centuries that follow. ${ }^{16}$

Because the idea of a chosen missionary people is inherently multilayered, and did not spring into being fully formed and unchallenged, we should not be surprised to find a lack of explicit and coherent articulations of the belief that the English were chosen by God for the purpose of missionizing other peoples. Nor, however, can we conclude from this that the Anglo-Saxons had no sense of being chosen and called to mission. This article deconstructs

13 Smith, Chosen Peoples, 49, 95-96. Smith characterized the English as an outwardly oriented "missionary people« but not on the basis of developments during the Anglo-Saxon period: 115-123.

14 Smith, Chosen Peoples, 50-51, 95.

15 Garrison, Franks as the New Israel; Divine Election for Nations.

16 For the Christian appropriation of the narrative of the chosen people from the Hebrew Bible with particular reference to 1 Peter 2.9-10, see Horrell, >Race`, >Nation`, >People‘; Beentjes, `Holy People‘. For early Christian writers, see Lieu, Race of the God-Fearers; Buell, Why This New Race. 
the idea of a chosen missionary people to examine each layer in turn. It first discusses the criteria Anglo-Saxon missionaries used to define ethnic groups, particularly their own. Then follows a survey of evidence that the missionaries believed their own people to be specially chosen or favoured by God. Only then is the question addressed whether being the recipient of divine favour also included an element of missionary purpose.

\section{People}

The nature of early medieval ethnicity has been the subject of considerable debate. ${ }^{17}$ It is clear from a historical perspective that ethnic groups are not stable entities moving through history, but they form, change, and disappear over time as individuals accept, rewrite, or reject narratives that connect them to others. ${ }^{18}$ But although ethnic groups are constructed, they are built on a foundation of perceived commonalities - some of which were believed to be inborn. ${ }^{19}$ Scholars have proposed several features that may have acted as ethnic markers and so contributed to the formation of ethnic groups in the early middle ages, including language, custom, religion, homeland, and (supposed) ancestry. ${ }^{20}$ Which of these features did the Anglo-Saxon missionaries consider salient? With whom could they imagine themselves a community? This article cannot treat these questions exhaustively, but it is necessary to give them some consideration, since whether Willibrord, Boniface, and others like them considered themselves as representatives of a chosen missionary people will depend in large part on who they saw as stheir peopler, and why. I argue that they identified themselves with the Angli, a people united by faith, ancestry, and homeland.

As noted above, early Christian writers had sometimes framed Christianity itself as an ethnicity. Something of that tradition is reflected in the way our missionary sources construct the binary Christian-pagan. 'The pagans` form their own catch-all category for all non-Christian peoples in more than one list of ethnic groups in Boniface's letters. ${ }^{21}$ The idea of a collective that might be termed sthe Christian peopler, however, is never fully articulated, despite hints at a unity that binds all Christians together. In one of the (pseudo-)Bonifatian sermons we find that the community of faith transcends earthly boundaries and makes all Christians sneighbours and `brothers - perhaps implying that geography and earthly descent cannot function as boundary markers between peoples within the universal church. ${ }^{22}$ In a letter to Archbishop Nothelm of Canterbury, Boniface notes that »it is well established that by holy baptism we all become sons and daughters, brothers and sisters of Christ and the Church. $\aleph^{23}$ Although this might seem to stress the importance of religious commonality,

17 For an overview, see Pohl, Conceptions of Ethnicity; for the Anglo-Saxons, see Frantzen, Anglo-Saxon Keywords, s.v. »Race."

18 Geary, Ethnicity as a Situational Construct.

19 Pohl, Introduction: Ethnicity, Religion and Empire, 10.

20 Geary, Ethnicity as a Situational Construct; Bartlett, Medieval and Modern Concepts. On the Anglo-Saxons, see among others Reynolds, What Do We Mean by Anglo-Saxon; Hines, Becoming of the English; Foot, Making of Angelcynn; Charles-Edwards, Making of Nations; Brooks, Canterbury; Yorke, Anglo-Saxon Origin Legends.

21 Boniface, Epistola 73, 78, ed. Tangl, 151 ll. 16-17, 171 ll. 17-18.

22 Si forte quislibet quaerat sit proximus, sciat omnem Christianum recte proximum dici, quia omnes in baptismo filii Dei sanctificamur, ut fratres simus spiritualiter in charitate perfecta, (Pseudo)-Boniface, Sermones (Pseudo)-Bonifatii, PL 89, col. 857D.

23 ... quando omnes in sacro baptismate Christi et ecclesiae filii et filiae fratres et sorores esse comprobemur. Boniface, Epistola 33, ed. Tangl, 58, 11. 8-10, trans. Emerton, Letters of Saint Boniface, 41. 
Boniface's point in this letter is actually the opposite: he is reacting against the reification of spiritual bonds that creates obstacles to marriage between biologically unrelated individuals. The church-as-people motif of early Christian literature is thus not taken up. Nevertheless, faith remains connected to ethnicity. It is taken for granted that a people would have a common faith, and that conversion means collective conversion. Bishop Torthelm of Leicester urged Boniface to "make haste... to gather [the Saxons] together and dedicate them to Christ as a new people. ${ }^{24}$ The missionaries' own people is also united by a shared faith: the roots of the English church in the Roman mission are recalled in several of Boniface's letters, and the strong Christian faith of the English people is praised in missionary hagiography. ${ }^{25}$

Bonds of kinship, whether real or imagined, were equally important to the unity of a people. Kinship is, in both Latin and Old English, etymologically implied in the very words for 'peoples, and biblically literate missionaries would also have been familiar with the Genesis account of how Noah's offspring became progenitors of all the world's peoples, "according to... their families in their nations ${ }^{26}{ }^{26}$ It comes as no surprise, then, to find ancestral ties featuring as ethnic markers in Boniface's correspondence. In perhaps his most famous letter, written to secure support for his mission among the Saxons, he addresses himself to everyone "of the lineage and stock of the English" (de stirpe et prosapia Anglorum) and identifies himself as »born of that same race" (procreatis eiusdem generis), suggesting a commonality among all the Anglo-Saxons based on common descent. ${ }^{27}$ Similarly, the consortium of bishops that signed Boniface's letter to Herefrid identified itself as "born of the English people" (de... Anglorum gente nati). ${ }^{28}$ The English people is thus presented as a collective into which one is born, and to which one belongs on account of one's lineage.

Lastly, the missionaries' self-identifications frequently make reference to their homeland, and the keen sense of separation from it which they experienced. Willibrord's autobiographical note in the Echternach Calendar begins by recording that he "came from beyond the sea" (veniebat ultra mare). ${ }^{29}$ Boniface calls himself an "exile in Germany" (exul Germanicus), and paints his mission as a long voyage or pilgrimage on which his companions are fellow-pilgrims. ${ }^{30}$ One of his favourite images for his mission is that of a ship drifting on the ocean:

I urge you to implore for me our merciful God, who is the author of our wanderings, that He will hold our frail vessel in His guiding and protecting hand, preserve it from the waves of German tempests, and bring it safely to the peaceful shore of the heavenly Jerusalem. ${ }^{31}$

24 Festinet... uti novum christo populum coacervare et dedicare. Torthelm of Leicester, Epistola 47, ed. Tangl, $76 \mathrm{ll}$. $18-20$.

25 Boniface, Epistola 33, 50, 73 ed. Tangl, 57-58, 84, 152; Vita Lebuini antiqua 1, ed. Hofmeister, 791: Anglorum patria, quae beati papae Gregorii studio ad Christianitatem perducta est, in fide Christi semper religiosissima erat.

26 Genesis 10.5.

27 Boniface, Epistola 46, ed. Tangl, 74 ll. 25-26.

28 Boniface, Epistola 74, ed. Tangl, 157 ll. 2-3.

29 Calendar of St Willibrord, ed. Wilson. The note is found on plate XI in Wilson's facsimile (folio 39b), the transcription on page 11 and notes at 42-43. On the identity of the scribe: Howlett, Willibrord's Autobiographical Note.

30 Boniface, Epistola 30, ed. Tangl, 54 l. 11.

31 ... ut pius Dominus, qui cause est peregrinationis nostrae, navem fragilitatis nostrae, ne fluctibus Germanicarum tempestatum submergatur, dextera sua protegente et gubernante inlesam custodiendo ad caelestis Hierusalem litus tranquillum perducat.« Boniface, Epistola 38, ed. Tangl, 63 ll. 11-15, trans. Emerton, Letters of Saint Boniface, 44. 
The expanse of sea separating Boniface from his homeland is likewise a recurring theme in his correspondence. Both he and his friends in Britain were acutely aware of the voyage over land and water needed to enable communication between them. Abbess Eangyth and her daughter Heaburg write that Boniface is divided from them by "a wide expanse of sea and land " (longo intervallo terre marisque). ${ }^{32}$ The contrast between those who remain in their "native land" (patrius) and those who have left their "native shores" (patria litora) on pilgrimage runs throughout the letter. By characterizing themselves as exiles and pilgrims, the missionaries tacitly posit their continuing connection to the homeland from which they are separated, and to its inhabitants. ${ }^{33}$ That homeland is primarily defined by the sea that surrounds it, so that the whole of Britain, rather than any specific kingdom or province within it, is in view.

Summing up, for the Anglo-Saxon missionaries, perceptions of who together formed a people were shaped by religion, genealogy, and geography. Theirs, correspondingly, was a Christian, Germanic, Britain-dwelling people - a people ever more frequently called by the name Angli, which had once belonged to a smaller collective but now was applied more broadly. Although Boniface is a 'Saxon< according to Bede's threefold division of the AngloSaxon peoples into Angles, Saxons, and Jutes, he does not hesitate to describe himself as belonging to the gens Anglorum, nor does he acknowledge any ethnic boundaries between himself and his correspondents of 'Anglian` or Jutish stock. The ethnonym Saxones underwent a similar broadening, but became the less popular choice for designating this 'English collective, quite possibly because of a desire to emphasize the difference between the AngloSaxons and the pagan Germanic peoples of the continent. ${ }^{34}$

\section{Chosen people: objects of divine favour}

Sources connected with the Anglo-Saxon missions to the continent make no explicit claims that the Angli are a snew Israek or chosen people. Nevertheless, there is some evidence that Anglo-Saxon missionaries viewed their own people and especially the English church as enjoying a special status. Some of the clearest indications are found in a letter from Boniface to King Æthelbald of Mercia. The letter was composed towards the end of the 740s, and signed by seven bishops besides Boniface himself. It was carried to Britain with accompanying letters to Archbishop Ecgbert of York, who was asked to emend the letter, and to the local priest Herefrid, who was asked to read and explain it to the king. ${ }^{35}$ The effort Boniface put into the composition and transmission of this letter was not without reason: the letter's purpose was to reprimand the king for his (sexual and political) sins. Boniface painted a bleak picture of the future of the English if Æthelbald were to persist in his errant ways:

"This is held to be a shame and a disgrace, not by Christians only but even by pagans. [...] If the English people, as is reported here and as is charged against us in France and Italy and even by the heathen themselves, are scorning lawful marriage and living in wanton adultery like the people of Sodom, then we must expect that [...] the

Eangyth and Heaburg, Epistola 14, ed. Tangl, 25 ll. 1-3, trans. Emerton, Letters of Saint Boniface, 16.

Pohl, Ethnic Names and Identities, 19-20; Palmer, Anglo-Saxons in a Frankish World, 50-51.

Boniface, Epistolae 74-75, ed. Tangl, 155-158. For a reflection on the relationship between preserved text and the oral (and vernacular) communication between Herefrid and Æthelbert, see Scior, Stimme, Schrift und Performanz. 
whole race will become debased and finally will be neither strong in war nor steadfast in faith, neither honored among men nor pleasing in the sight of God. So it has been with the peoples of Spain and Provence and Burgundy. They turned thus away from God and lived in harlotry until the Almighty Judge let the penalties for such crimes fall upon them through ignorance of the law of God and the coming of the Saracens. ${ }^{36}$

At first glance, this passage suggests that the English are on equal footing with the other Christian peoples of Europe, indeed it is implied that at the moment they compare rather unfavourably with the Franks and Italians where moral rectitude is concerned. However, the doom which Boniface saw hanging over the English was a loss of the status which, so the threat implied, they currently still possessed. They had until then been, and, if Æthelbald repented, would continue to be, "strong in war" and "steadfast in faith ", "honoured among men « and "pleasing in the sight of God". National honour and national shame are flip sides of the same coin. ${ }^{37}$ The moral standards and reputation of the English are addressed in a number of other letters also: the moral standing of the Angli is a theme in a letter to Archbishop Cuthbert of Canterbury, and in the letter to Herefrid that accompanied the missive for Æthelbald, Boniface and the other senders wrote that "[t]he well-doing and the fair fame of our race is our joy and delight; their sins and their evil repute fill us with grief and sorrow" (Bonis et laudibus gentis nostrae laetamur et gaudemus, peccatis autem eius et vituperationibus eius tribulamur et contristamur)..$^{8}$ This dynamic of divine favor and retribution in response to the moral standing of the people and its leaders closely resembles the covenantal form of ethnic election as described by Smith. ${ }^{39}$

Other passages in the letter to Æthelbald underscore the favoured position of the Angli by recalling their illustrious history as a godly people..$^{40}$ Boniface and his co-signatories prayed that God would keep Æthelbald »safe and steadfast in faith and works before God and in the leadership of the people of Christ " (sospites et in fide stabiles et in operibus coram Deo rectos in principatu christiani populi), clearly signalling divine approval of Æthelbald and the "people of Christ« over whom he rules..$^{41}$ The opening lines of the letter address Æthelbald as "gloriously governing the empire of the English" (inclita Anglorum imperii sceptra gubernanti). ${ }^{42}$ No doubt this was an exaggeration intended to flatter the letter's recipient, but even so the language recalls the imperial grandeur of Rome and implies that the Angli are its heirs. ${ }^{43}$

36 Quod non solum a christianis, sed etiam a paganis in opbrorium et verecundiam deputatur. [...] Si enim gens Anglorum, sicut per istas provincias devulgatum est et nobis in Francia et in Italia inproperatur et ab ipsis paganis inproperium est, spretis legalibus conubiis adulterando et luxoriando ad instar Sodomitane gentis foedam vitam vixerit, [...] aestimandum est [...] ad extremum universam plebem ad deteriora et ignobiliora vergentem et novissime nec in bello saeculari fortem nec in fide stabilem et nec honorabilem hominibus nec Deo amabilem esse venturam. Sicut aliis gentibus Hispaniae et Prouinciae et Burgundionum populis contigit; quae sic a Deo recedentes fornicate sunt, donec iudex omnipotens talium criminum ultrices poenas per ignorantiam legis Dei et per Sarracenos venire et sęrvire permisit. Boniface, Epistola 73, ed.Tangl, 150-151, trans. Emerton, Letters of Saint Boniface, 105-106.

37 "National shame« is mentioned in this context by Wormald, Bede, the Bretwaldas and the Origins, 119.

38 Boniface, Epistola 78, 74, ed. Tangl, 161-170, 156 ll. 4-6, trans. Emerton, Letters of Saint Boniface, 109.

39 Smith, Chosen Peoples, 50-51.

40 Boniface, Epistola 73, ed. Tangl, 152.

41 Boniface, Epistola 73, ed. Tangl, 147 ll. 7-9, trans. Emerton, Letters of Saint Boniface, 103.

42 Boniface, Epistola 73, ed. Tangl, 146 ll. 24-25.

43 Contrast Boniface's letter to Pippin which addresses him more soberly as »domino excellentissimo... regi Francorum. « Boniface, Epistola 107, ed. Tangl, 233 l. 1. 
Personal connections provide another piece of evidence to suggest a sense that the Angli were a specially favoured people. Unlike Irish missionary pilgrims, English missionaries did not sever all ties with their past life, but remained embedded in their social networks, keeping open the possibility of return, and using their connections to secure moral and practical support. ${ }^{44}$ They frequently invited others from England to participate in the mission or take on leadership roles in newly established dioceses and monasteries, favouring their compatriots over locally trained religious. Willibrord himself came to the continent at the suggestion of another English missionary, Ecgbert (639-739), who had already been attempting to coordinate a Frisian mission for some time. ${ }^{45}$ Clerics from Willibrord's circle, upon choosing Swithberht for their bishop, sent him to England for ordination - a decision that has yet to be satisfactorily explained, but says something of the close links maintained between the missionaries and the Anglo-Saxon church. ${ }^{46}$ Boniface's earliest biographer writes that »[f]rom Britain an exceedingly large number of holy men came to his aid. « ${ }^{47}$ Similarly the author of the Life of Leoba recalls that Boniface "sent messengers and letters to England, his native land, summoning from different ranks of the clergy many who were learned in the divine law and fitted both by their character and good works to preach the Word of God. $\aleph^{48}$ Boniface himself informed Fulrad (abbot of St Denis, 750-784) that his fellow-workers were "nearly all foreigners" (pene omnes peregrini), and his most trusted associates were Englishmen like himself. ${ }^{49}$ These included Denehard, who acted repeatedly as Boniface's messenger and was his representative to the Roman synod of 745, and Lull, whom Boniface appointed as his successor..$^{50}$ After establishing three new dioceses in 741 or 742, Boniface consecrated at least two Englishmen to serve as diocesan bishops: Burchard for Würzburg and Wintan for Büraburg. ${ }^{51}$ The identity of the third bishop, appointed to Erfurt, is unknown. Perhaps Boniface originally had the West-Saxon Willibald in mind, whom he consecrated bishop at this time, but Willibald left the region to found a monastery in Eichstätt. ${ }^{52}$ Boniface's monastic foundations were likewise headed by English men and women: the house at Tauberbischofsheim was entrusted to Leoba (d. 782), with whom he had corresponded while she was still in England; his monastic foundation at Fritzlar was placed under the leadership of

44 Palmer, Anglo-Saxons in a Frankish World, 67, 72-75.

45 Bede, Historia ecclesiastica gentis Anglorum 5.9-10, ed. Colgrave and Mynors, 474-485; Mayr-Harting, Ecgberht.

46 Bede, Historia ecclesiastica gentis Anglorum V,11, ed. Colgrave and Mynors, 484-487; Ziegler, Ripon Connection.

47 Et ex Brittaniae partibus servorum Dei plurima ad eum [...] convenerat multitudo, Willibald, Vita Bonifatii 6, ed. Levison, 34, trans. Talbot, Anglo-Saxon Missionaries, 47.

48 ... in terram Anglorum, unde ipse ex parentibus erat, legatos et epistolas misit atque ex diverso clericorum ordine nonnullos accersivit doctos lege divina et ad praedicationem verbi vitae merito morumque probitate idoneos, quorum adminiculo iniunctam sibi legationem non segniter administravit. Rudolf of Fulda, Vita Leobae 9, ed. Waitz, 125 ll. 40-42, trans. Talbot, Anglo-Saxon Missionaries, 213.

49 Boniface, Epistola 93, ed. Tangl, 213 l.11.

50 Denehard and Lull describe themselves to Abbess Cuniberg in Britain as her "fellow countrymen " (vernaculi) who "went over to the German peoples" (ad Germanicas gentes transivimus) after the death of their relatives. They ask her to send still others over to them. Denehard, Lull and Burchard, Epistola 49, ed. Tangl, 78-80; Emerton, Letters of Saint Boniface, 53-54.

51 Boniface reports these events in Epistola 50, ed. Tangl, 81. Wintan signed Boniface's letter to king Æthelbert and the accompanying letter to Herefrid, in which the authors identify themselves as "born and bred of that same English stock (de eadem Anglorum gente nati et nutriti). Boniface, Epistola 74, ed. Tangl, 156 1l. 2-3; Burchard is, together with Lull and Denehard, author of the letter to Cuniberg, Epistola 49, ed. Tangl, 78.

52 Larrington, Willibald. 
Abbot Wigbert (d. ca. 737) and succeeded on Boniface's orders by Tatwin, both of whom bear English names. ${ }^{53}$ The tendency to favour Anglo-Saxons for positions of influence expresses a subtle sense of superiority, and a greater trust in the orthodoxy and capability of English missionaries than in those of local leaders.

We must at this point address an alternative explanation for the missionaries' preference for English company: that they were drawing on their family networks. This is the interpretation put forward by Ian Wood, who argues that the two waves of missionaries, centred on Willibrord and Boniface respectively, correspond with two kin groups. He sees the missions not as a national but as a familial enterprise. ${ }^{54}$ While it is true that some members of the missionary circles were related to one another - we know for instance that Leoba was related to Boniface, and so were Willibald, Wynnebald, and Hygeburg, who were involved in the missions in the mid to late eighth century - it is equally clear that some of those who became fellow missionaries were initially strangers to one another. ${ }^{55}$ Several letters in the Bonifatian correspondence testify to the connections forged between unrelated individuals in the course of the missions. ${ }^{56}$ Boniface and Willibrord, though they worked together closely for several years, were not related to one another and had spent their formative years in different parts of Britain. The ongoing recruitment of English missionaries must therefore point to a sense of commonality that encompassed not just the kin group, but the Angli at large.

This impression is strengthened by the fact that Anglo-Saxon missionaries showed a marked preference for English customs as well as for English individuals. Peter Brown characterized Boniface as one who »brought from the smicro-Christendom a blueprint of scorrect Christianity which he was quite prepared to impose on the ancient Christianity of Continental Europe. ${ }^{57}$ Many (though not all) of the abuses he found in the Frankish church could perhaps be better described as local traditions that were at odds with his own..$^{58}$ It is telling that several of the opponents Boniface considered heretics of the worst sort could count on considerable support from their own churches. As an example we might consider the Irishmen Clemens and Virgil whose ideas, insofar as we are able to reconstruct them, seem to be in line with broader tendencies and concerns in the Irish church, and to some degree had gained currency among the Franks. ${ }^{59}$ The Frankish bishop Adalbert, whom Boniface condemned, had gained a significant following among the people of Francia, who viewed him as "a most holy apostle... a patron and intercessor, a doer of righteousness and worker of miracles. ${ }^{60}$ Cases such as these reveal the extent to which Boniface's sense of >correct $\iota$ conduct and doctrine was the product of his English background.

53 Boniface, Epistola 29, 40, ed. Tangl, 52-53, 64-65.

54 Wood, Missionary Life, 91-92.

55 Rudolf of Fulda, Vita Leobae 10, ed. Waitz, 126; Hygeburg of Heidenheim, Vita Willibaldi prologue, 3, ed. Holder-Egger, 87, 90; Hygeburg of Heidenheim, Vita Wynnebaldi 4, ed. Holder-Egger, 109.

56 For instance: Eangyth and Heaburg, Epistola 14, ed. Tangl, 26 ll. 11-19, commend a certain Denewald to Boniface, indicating that he needed an introduction provided by a mutual friend. Denehard, Lull and Burchard, Epistola 49, ed. Tangl, 78-79, seem to suggest that they did not know Boniface before setting out for the continent; they also indicate that they only left Britain after their relatives had died. Wihtberht, Epistola 101, ed. Tangl, 224 1l. 10-21, recalls the warm welcome he received from Boniface, but his language does not suggest any prior acquaintance with him.

57 Brown, Rise of Western Christendom, 423-424.

58 Jong, Bonifatius; Keep, Cultural Conflicts, 48.

59 Carey, Ireland and the Antipodes; Meeder, Boniface and the Irish Heresy of Clemens.

60 ... sanctissimum apostolum... patronum et oratorem et virtutem factorem et signorum ostensorem. Anonymous, Epistola 59, ed. Tangl,111 ll. 11-13, trans. Emerton, Letters of Saint Boniface, 79. 
Although Willibrord seems to have been more comfortable than Boniface fusing together elements from Anglo-Saxon, Irish and Frankish traditions, he, too, unconsciously favoured the ways of the church in which he was brought up. ${ }^{61}$ Bede informs us, based on an eye-witness report by Acca of Hexham (d. 740), that Willibrord had relics of King Oswald of Northumbria (634-642) with him in Frisia, and was able to report miracles that took place in connection with them. ${ }^{62}$ Willibrord's calendar lists over a hundred saints, but local Frankish saints make up only a small minority while there is a strong presence of insular saints. ${ }^{63}$ The loyalty of Anglo-Saxon missionaries to English customs is revealed by the impact of English customs on the shape of Christian practice in the areas where Anglo-Saxon missionaries worked - for instance, in the adoption of private penance on the continent, and in Frankish liturgy. ${ }^{64}$

Not only specific English practices and beliefs were exported by the Anglo-Saxon missionaries, but also the general structure of the English church. That structure encompassed a geographic organization in which churches were spread regularly across the landscape, and an episcopal government under archbishops who oversaw the church of a whole gens, themselves appointed by and accountable to the pope. ${ }^{65}$ Joanna Story has argued that the presence in Willibrord's calendar of two letters from Pope Honorius (625-638) regarding the establishment of the archiepiscopal see of York indicates that Willibrord may have wanted to shape his own archbishopric of Frisia after the pattern of that of Northumbria. ${ }^{66}$ Boniface inspired by the example of the English church, made much of the need for regular synods, and the Frankish synods conducted under his leadership »no doubt employed the English [...] procedures to which he was already accustomed. ${ }^{67}$ The continental churches, both new and old, were thus to be organized according to the model provided by the English church. The Anglo-Saxon missionaries' maintenance of strong links to their homeland and their loyalty to its customs indicate that they felt the English people to be somehow special, exemplary. Though they presented themselves as upholding universal standards of orthodoxy, it was in fact the English church that most often set the norm, whether for doctrine, liturgy, pastoral care, or ecclesial organization. ${ }^{68}$ The Angli are thus treated as heirs and present guardians of the truest Christian tradition.

This sense of the special position of the Angli remained largely unarticulated. We might account for this by recalling the dependence of the missionaries' work on the goodwill of Frankish rulers. ${ }^{69}$ In this context, claims to be representatives of a chosen people set apart from and above the other Christian peoples of Europe could only have served to alienate those

61 Wood, Missionary Life, 80; Hen, Liturgy of St Willibrord, 54.

62 Bede, Historia ecclesiastica gentis Anglorum 3,13.

63 Hen, Liturgy of St Willibrord, 54; Gerchow, Gedenküberlieferung der Angelsachsen, 199-212, esp. 200.

64 Meens, Frequency and Nature; Hen, Rome.

65 Clay, Saint Boniface's Pastoral Strategy; Levison, England and the Continent, 59 and passim. On the unique character of the Anglo-Saxon higher episcopate in this period, see Thacker, Gallic or Greek?

66 Story, Bede, Willibrord and the Letters of Pope Honorius I.

67 McKitterick, Frankish Church, 12. On the relationship between Boniface's »German« synod and the English synod at Clofesho, see Vollrath, Synoden Englands, 150-156; Cubitt, Anglo-Saxon Church Councils, 102-110.

68 Innes, >Immune from Heresy<, 105-106.

69 Boniface, Epistola 63, ed. Tangl, 129-130; Wood, Missionary Life, 57. On Willibrord's relationship with the Pippinids and Carolingians see Claussen, Reform of the Frankish Church, 33-35; Angenendt, Willibrord im Dienste der Karolinger, 67-82. For the charters granting land to Willibrord, see Wampach, Geschichte der Grundherrschaft Echternach. 
upon whom their work relied. It is hardly surprising that the clearest suggestions that the Angli are the recipients of special divine favour are made in a context where the audience is likely to find such notions appealing: in communications to the leaders of the English people and church. The promise of divine favour and the fear of divine retribution are expertly wielded to exhort Æthelbald to repent. Yet the favour bestowed upon the Angli is not strictly exclusive to them, nor is it unconditional: the Mercian monarch is warned by the fates of other kings and nations who had once enjoyed God's favour but lost it when they spurned his law. The Angli may be specially favoured, but the favour comes with and is contingent upon the requirement that they uphold high standards of orthodoxy and morality.

\section{Purposed election: chosen for mission?}

If there are indications that Anglo-Saxon missionaries felt the English people and church to hold a special and favoured position before God because they had received and upheld the tradition of apostolic orthodoxy, did such a position bring with it an obligation to engage in missionary work? This notion does not feature as a rationale for the missionaries themselves in the sources produced by the circles of Willibrord and Boniface. In the Bonifatian correspondence, the closest we come to the articulation of a sense that the missions were an answer to a collective calling is in a letter from Cuthbert of Canterbury to Lull, Boniface's successor as bishop of Mainz, prompted by Boniface's death in 754. Cuthbert reported that a recent council of the English church had decided to honour Boniface as a patron saint alongside Gregory the Great and Augustine of Canterbury. He rejoices, he says, "that the English people [...] merited to laudably send forth such a distinguished soldier of Christ. « ${ }^{70}$ By placing the great missionary brought forth by England on a par with those who first brought (Roman) Christianity to the Anglo-Saxons, and taking these three as the special patrons of the Anglo-Saxons, Cuthbert made the spreading of the gospel as central to Anglo-Saxon Christian identity as receiving it, and suggested that Boniface's efforts were not only to his own credit, but also reflected well upon his compatriots, of whom he was claimed to be a representative - first on earth, and now in heaven. We hear a similar note of national pride in Alcuin's excursus on the English missions in his poem on York which was cited at the beginning of this article, and we can assume he expected his audience, the "young men of York" (Euboricae... iuventus), to share the sentiment. ${ }^{71}$ This suggests that at least some of the missionaries' contemporaries and successors saw their work as part of a larger narrative.

However, what evidence we have for the motivations of the missionaries themselves suggests that they understood their work as a response to a general Christian calling, rather than a specific calling of the Angli, to missions. Boniface must have been aware, as was Cuthbert, of similarities between himself and the missionary Augustine. That much can be inferred from his interest in Gregory's Libellus, which offered practical advice to the Roman missionaries in Kent at the turn of the seventh century. ${ }^{72}$ As noted above, Nicholas Howe has argued that Boniface actively sought to pattern his own mission after that of Augustine, and, by going from island to continent just as Augustine had gone from continent to island, presented himself and his work as the completion of Augustine's mission. ${ }^{73}$ These suggestions are part

70 ... quod tam [...] egregium Christi militem [...] gens Anglorum advena Brittania meruit [...] laudabiliter emittere. Cuthbert, Epistola 111, ed. Tangl, 239-240.

71 Alcuin, Versus de patribus, regibus et sanctis Eboracensis ecclesiae l. 1409, ed./trans. Godman, 110.

72 Boniface, Epistola 33, ed. Tangl, 57; see also Elliot, Boniface, Incest, and Gregory I's Libellus.

73 Howe, Migration and Mythmaking, 127-128, 130-133, 140.

medieval worlds $\bullet$ No. $3 \cdot 2016 \cdot 98-115$ 
of Howe's larger argument that the Anglo-Saxon missions of the eighth century were seen by contemporary Anglo-Saxons as the necessary counterpart to their people's migration from the continent to Britain and subsequent conversion. In this interpretation, Boniface and other missionaries saw themselves as "representative[s] of a converted Germanic people« who desired, indeed felt obligated, to complete the divinely fore-ordained trajectory of their people's history through $» r e t u r n$ migration $« .{ }^{74}$ But while it is clear that Boniface was interested in Augustine's mission and deeply invested in the link that began with him between the English and the Roman church, the far more obvious pattern for his self-understanding as a missionary is provided by the Scriptures. Boniface's descriptions of his own missionary work are peppered with quotations from the letters of Paul. ${ }^{75}$ Boniface's concerns that he would be found spiritually childless echo the words put in his mouth by Gregory III: "Here am I, and the children you have given me" (Ecce ego, et pueri, quos dedisti mihi), words which are drawn from the epistle to the Hebrews (2.13). ${ }^{76}$ Maintaining the biblical register, Boniface wrote that he did not want to "hide his talent" (abscondito talento, cf. Matthew 25.25) or have his work prove "unfruitful (infructuosi, cf. Titus 3.14). ${ }^{77}$ Willibrord, too, is reported to have modeled himself after the first apostles by setting out in a group of twelve, and the sole scrap of writing from his own pen says of his motivation only that he undertook his missionary work "in the name of God « (in nomine Dei). ${ }^{78}$ The key themes that emerge from the missionaries' own accounts of their work are thus the mission of the church as a whole, and their own personal spiritual formation.

Boniface's famed letter to "all Catholics of the English race" (omnibus catholicis ... de stirpe et prosapia Anglorum) does indicate that he believed mission ought to have been a widely shared concern among his compatriots. ${ }^{79}$ His appeal to the Angli as an ethnic community is, however, not primarily intended to inspire a general missionary zeal, but specifically to garner support for his project of converting the Saxons with whom the addressees are so movingly described as sharing "blood and bone" (De uno sanguine et de uno osse sumus). ${ }^{80}$ The appeal to this shared origin features in other letters, too. Clay has demonstrated that Boniface used the adjective sgermanicus in his correspondence to evoke "powerful connotations that resonated especially with readers who located the primeval origins of their own gens in Germania itself. ${ }^{81}$ The emphasis on the conversion of the continental peoples to whom they felt ethnically closest, suggests that these pagan peoples may have been considered in some sense relect r as well: destined to receive the gospel and share with the Angli in God's favour. It is interesting in this connection to note Torthelm's description of Boniface's prospective

74 Howe, Migration and Mythmaking, 141-142, 125.

75 E.g. Boniface, Epistola 65, ed. Tangl, 137-138; Boniface, Epistola 76, ed. Tangl,158-159. Gregory II charged Boniface to imitate the apostles: Gregory II, Epistola 24, ed. Tangl, 42.

76 Gregory III, Epistola 45, ed. Tangl, 74 l.1; Boniface, Epistola 67, ed. Tangl,140 ll.3-4.

77 Boniface, Epistola 67, ed. Tangl, 140 ll. 4-6. On Boniface's missionary terminology, see Clay, In the Shadow of Death, 238-248, with Appendix 1, 405-410.

78 Bede, Historia ecclesiastica gentis Anglorum 5.10, ed. Colgrave and Mynors, 480-481; Alcuin, Vita Willibrordi 5, ed. Levison, 120; Calendar of St Willibrord, ed. Wilson, 11.

79 Boniface, Epistola 46, ed. Tangl, 74 ll. 24-25. However, it may not have been: Palmer, Anglo-Saxons in a Frankish World, 8.

80 Boniface, Epistola 46, ed. Tangl, 75 l. 6.

81 Clay, In the Shadow of Death, 269. 
converts in Saxony as "our people" (gens nostra).$^{82}$ By stretching ethnic boundaries to include the continental peoples to whom they are linked by common ancestry and erstwhile homeland, those Anglo-Saxons who were favourably disposed towards continental missions could make a case for the inclusion of the pagans of Germania among God's elect. ${ }^{83}$

A sense of collective calling as a people does not, therefore, emerge as a factor that drove Anglo-Saxons like Willibrord and Boniface to undertake missions to the continent. One might argue, however, that there is a sense in which the belief that the Angli were spiritually superior to other peoples was a necessary premise on which missionary work could be based. As I argue above, the missionaries do demonstrate such a sense of superiority and seem to envision an exemplary role for the English church. However, there is no suggestion that failure to engage in mission would lead to the withdrawal of divine favour from the Angli in the same way that (ongoing and publicly sanctioned) immorality would. Mission was therefore not part and parcel of the special status of the English, even though perhaps some of the missionaries were inspired by a belief that if the Angli were a chosen people, then so must be their continental cousins, and therefore destined to embrace the faith.

\section{Concluding Remarks}

The evidence for a belief in a divine election of the Angli is often indirect and open to multiple interpretations. However, the suggestion that the Anglo-Saxon missionaries held such a belief holds significant explanatory power. It provides a mechanism through which we can understand not only specific references to divine favour and retribution, but also the consistent favouring of English persons and practices over continental ones. Although this belief remained unarticulated, and indeed may have been largely unconsciously held, it nevertheless appears to have been very real in its practical outworking. Missionaries from the circles of Willibrord and Boniface treated the Angli as a divinely favoured people, even if they did not always speak of them as such. The themes of national pride and shame, and indeed references to any sense of ethnic identity as expressed through bonds of kinship and homeland, are most clearly present in texts written for English audiences. This holds true both for the texts produced by the missionaries themselves, and for later commemorative texts. In his poem intended for a Northumbrian audience, Alcuin stressed the ethnicity of the missionaries, but in his Life of Willibrord, written for the community at Echternach, he focused on the family connections of the saint and the place of his missionary work in Christian, rather than in a national history. ${ }^{84}$ Cuthbert, writing to his compatriot Lull, made Boniface the patron of the Angli; Willibald's Life of Boniface, aimed at a wide readership across western Europe, foregrounds the connections with Rome, with the Frankish establishment, and with Mainz. ${ }^{85}$ The diversity of lenses through which the missions could be viewed serves as a reminder that the missionaries were embedded in many social groups, of which the ethnic group known as the Angli was only one. As they came to be venerated as saints and martyrs, many attempts

82 Torthelm of Leicester, Epistola 47, ed. Tangl, 76 1. 10.

83 But compare Boniface, Epistola 38, ed. Tangl, 62 1l. 22-27, for an alternative angle: Petimus quoque, ut pro Germanicis gentis ... intercedere curetis, rogantes Dominum, qui pro totius mundi salute proprium sanguinem fudit et svult omnes homines salvos fieri et ad agnitionem veritatis venirer, ut eas ad agnitionem et ad gremium matris aecclesiae convertat.

84 Rambridge, Alcuin's Narratives of Evangelism.

85 Willibald, Vita Bonifatii, prol. 2 1l. 27-29. 
were made to claim a special connection with them and bask in their reflected glow. One particularly striking example occurred centuries later, when the Frisians came to see Willibrord and Boniface as a new Moses and Joshua who had led them, the chosen people, from pagan bondage to Christian freedom. ${ }^{86}$ In this tradition, Willibrord even came to be viewed as a Frisian, entirely removed from his English context. ${ }^{87}$ This recasting of the Anglo-Saxon missionaries as heroes in another national story altogether serves to show how easily the original motivations and experiences of the missionaries themselves can be lost in retrospective interpretations. Although the missionary circles of Willibrord and Boniface seem to have felt that their people enjoyed a special status, their missions were understood against a far wider backdrop.

86 Bremmer, Willibrord through Anglo-Saxon and Frisian Eyes, 13-14.

87 Bremmer, Willibrord through Anglo-Saxon and Frisian Eyes, 18. 


\section{References}

Alcuin, Versus de patribus, regibus et sanctis Eboracensis ecclesiae, ed. and trans. Peter Godman, The Bishops, Kings and Saints of York, Oxford Medieval Texts (Oxford, 1982).

Alcuin. Vita Willibrordi archiepiscopi Traiectensis auctore Alcvino, ed. Wilhelm Levison, MGH SS rerum Merovingicarum 7 (Hannover, 1920) 81-141.

Angenendt, Arnold, Willibrord im Dienste der Karolinger, Annalen des historischen Vereins für den Niederrhein 175 (1973) 63-113.

Boniface, Epistolae, ed. Michael Tangl, S. Bonifacii et Lulli Epistolae MGH, Epistolae Sel. I, (Berlin, 1916).

Boniface, The Letters of Saint Boniface, ed. and trans. Ephraim Emerton, with a new introduction and bibliography by Thomas F. X. Noble (New York, 2000).

Pseudo-Boniface, Sermones Pseudo-Bonifatii, PL 89.

Bartlett, Robert, Medieval and Modern Concepts of Race and Ethnicity, Journal of Medieval and Early Modern Studies 31/1 (2001) 39-56.

Bede, Historia ecclesiastica gentis Anglorum, ed. and trans. Bertram Colgrave and Roger A.B. Mynors, Bede's Ecclesiastical History of the English People (Oxford, 1993).

Beentjes, Pancratius C., ,Holy Peoples: The Biblical Evidence, in: Marcel Poorthuis and Joshua Schwartz (eds.), A Holy People: Jewish and Christian Perspectives on Religious Communal Identity (Leiden, 2006), 3-15.

Bremmer, Rolf H. Jr., Willibrord through Anglo-Saxon and Frisian Eyes: From History to Myth, in: Volkert F. Faltings, Alastair G.H. Walker and Ommo Wilts (eds.), Friesische Studien I: Beiträge des Föhrer Symposiums zur friesischen Philologie vom 10.-11. Oktober 1991 (Odense, 1992) $1-28$.

Brooks, Nicholas, Canterbury, Rome and the Construction of English Identity, in: Julia M.H. Smith (ed.), Early Medieval Rome and the Christian West: Essays in Honour of Donald A. Bullough (Leiden, 2000) 221-46.

Brown, Peter, The Rise of Western Christendom: Triumph and Diversity, A.D. 200-100o (10th anniversary revised edition), (Malden, 2012).

Buell, Denise Kimber, Why This New Race: Ethnic Reasoning in Early Christianity (New York, 2005).

Carey, John, Ireland and the Antipodes: The Heterodoxy of Virgil of Salzburg, Speculum 64/1 (1989) 1-10.

Charles-Edwards, Thomas M., The Making of Nations in Britain and Ireland in the Early Middle Ages, in: Ralph Evans (ed.), Lordship and Learning: Studies in Memory of Trevor Aston (Woodbridge, 2004) 12-24.

Claussen, Michael A., The Reform of the Frankish Church: Chrodegang of Metz and the Regula Canonicorum in the Eighth Century (Cambridge, 2004).

Clay, John-Henry, In the Shadow of Death: Saint Boniface and the Conversion of Hessia, 721-754 (Turnhout, 2010).

Clay, John-Henry, Saint Boniface's Pastoral Strategy in Central Germany, 721-751, conference paper presented at the Early Medieval Monasticism in the North Sea Zone, University of Kent, April 25, 2015. Retrieved on 31 March 2016: https://www.academia.edu/12123631/ Saint_Bonifaces_pastoral_strategy_in_central_Germania_721-754.

Cubitt, Catherine, Anglo-Saxon Church Councils C. 650-C. 850 (London, 1995). 
Elliot, Michael D., Boniface, Incest, and the Earliest Extant Version of Pope Gregory I's Libellus Responsionum (JE 1843), Zeitschrift der Savigny-Stiftung für Rechtsgeschichte: Kanonistische Abteilung 100 (2014) 62-111.

Foley, William Trent, and Higham, Nicholas J., Bede on the Britons, Early Medieval Europe 17/2 (2009) 154-85.

Foot, Sarah, Bede's Church, Jarrow Lecture (Jarrow, 2012).

Foot, Sarah, The Making of Angelcynn: English Identity Before the Norman Conquest, Transactions of the Royal Historical Society 6 (1996) 25-49.

Frantzen, Allen J., Anglo-Saxon Keywords (Malden, 2012).

Garrison, Mary, Divine Election for Nations - a Difficult Rhetoric for Medieval Scholars? in: Lars Boje Mortensen (ed.), The Making of Christian Myths in the Periphery of Latin Christendom (1000-1300) (Copenhagen, 2006) 275-314.

Garrison, Mary, The Franks as the New Israel? Education for an Identity from Pippin to Charlemagne, in: Yitzhak Hen and Matthew Innes (eds.), The Uses of the Past in the Early Middle Ages (Cambridge, 2000) 114-61.

Geary, Patrick J., Ethnicity as a Situational Construct in the Early Middle Ages, Mitteilungen der anthropologischen Gesellschaft in Wien 113 (1983) 15-26.

Gerchow, Jan, Die Gedenküberlieferung der Angelsachsen: mit einem Katalog der libri vitae und Necrologien (Berlin, 1988).

Harris, Stephen J., Race and Ethnicity in Anglo-Saxon Literature (New York, 2003).

Hastings, Adrian, The Construction of Nationhood: Ethnicity, Religion and Nationalism (Cambridge, 1997).

Hen, Yitzhak, Rome, Anglo-Saxon England and the Formation of the Frankish Liturgy, Revue Bénédictine 112/3-4 (2002) 301-22.

Hen, Yitzhak, The Liturgy of St Willibrord, Anglo-Saxon England 26 (1997) 41-62.

Hines, John, The Becoming of the English: Identity, Material Culture and Language in Early Anglo-Saxon England, Anglo-Saxon Studies in Archaeology and History 7 (1994) 49-59.

Horrell, David G., >Raceく, >Nation<, >Peopleく: Ethnic Identity-Construction in 1 Peter 2.9, New Testament Studies 58/1 (2012) 123-43.

Howe, Nicholas, Migration and Mythmaking in Anglo-Saxon England (Notre Dame, 1989).

Howe, Nicholas, Writing the Map of Anglo-Saxon England: Essays in Cultural Geography (New Haven, 2008).

Howlett, David R., Willibrord's Autobiographical Note and the >Versus Sybillae de Iudicui Dei<, Peritia 20 (2008) 154-64.

Hygeburg of Heidenheim, Vita Willibaldi episcopi Eichstetensis, ed. Oswald Holder-Egger, MGH SS 15,1 (Hannover, 1887) 86-106.

Hygeburg of Heidenheim, Vita Wynnebaldi Abbatis Heidenheimensis, ed. Oswald Holder-Egger, MGH SS 15,2 (Hannover, 1887) 106-17.

Innes, Matthew, >Immune from Heresy<: Defining the Boundaries of Carolingian Christianity, in: Paul Fouracre and David Ganz (eds.), Frankland: The Franks and the World of the Early Middle Ages. Essays in Honour of Dame Jinty Nelson (Manchester, 2008) 101-25.

Jong, Mayke de, Bonifatius: Een Angelsaksische priester-monnik en het Frankische hof, Millennium 19 (2005) 5-23.

Keep, David, Cultural Conflicts in the Missions of Saint Boniface, in: Stuart Mews (ed.), Religion and National Identity (Oxford, 1982) 47-57. 
Larrington, Carolyne, Willibald [St Willibald] (c.700-787?), Oxford Dictionary of National Biography (Oxford, 2004). Retrieved on 31 March 2016: http://www.oxforddnb.com/view/ article/29575.

Levison, Wilhelm, England and the Continent in the Eighth Century, Ford Lectures 1943 (Oxford, 1956).

Lieu, Judith M., The Race of the God-Fearers, Journal of Theological Studies 46 (1995) 483502.

Mayr-Harting, Henry, Ecgberht (639-729), Oxford Dictionary of National Biography (Oxford, 2004). Retrieved on 31 March 2016: http://www.oxforddnb.com/view/article/8579.

McKitterick, Rosamond, The Frankish Church and the Carolingian Reforms, 789-895 (London, 1977).

Meeder, Sven, Boniface and the Irish Heresy of Clemens, Church History 80/2 (2011) 251-80.

Meens, Rob, The Frequency and Nature of Early Medieval Penance, in: Peter Biller and Alistair J. Minnis (eds.), Handling Sin: Confession in the Middle Ages (Woodbridge, 1998) 35-61.

Molyneaux, George, Did the English Really Think They Were God's Elect in the Anglo-Saxon Period? Journal of Ecclesiastical History 65/4 (2014) 721-37.

Molyneaux, George, The Old English Bede: English Ideology or Christian Instruction? The English Historical Review 124/511 (2009) 1289-1323.

Murray, Alexander, Bede and the Unchosen Race, in: Huw Pryce and John Watts (eds.), Power and Identity in the Middle Ages: Essays in Memory of Rees Davies (Oxford, 2007) 52-67.

Palmer, James T., Anglo-Saxons in a Frankish World, 690-900 (Turnhout, 2009).

Pohl, Walter, Conceptions of Ethnicity in Early Medieval Studies, in: Lester K. Little and Barbara H. Rosenwein (eds.), Debating the Middle Ages: Issues and Readings (Malden, 1998) 15-24.

Pohl, Walter, Ethnic Names and Identities in the British Isles: A Comparative Perspective, in: John Hines (ed.), The Anglo-Saxons from the Migration Period to the Eighth Century: An Ethnographic Perspective (Woodbridge, 1997) 7-40.

Pohl, Walter, Introduction: Ethnicity, Religion and Empire, in: Walter Pohl, Clemens Gantner, and Richard E. Payne (eds.), Visions of Community in the Post-Roman World: The West, Byzantium and the Islamic World, 300-110o (Farnham, 2012) 1-23.

Rambridge, Kate, Alcuin's Narratives of Evangelism: The Life of St Willibrord and the Northumbrian Hagiographical Tradition, in: Martin Carver (ed.), The Cross Goes North: Processes of Conversion in Northern Europe, AD 300-1300 (Woodbridge, 2006) 371-81.

Reynolds, S., What Do We Mean by Anglo-Saxon and the Anglo-Saxons? Journal of British Studies 24/4 (1985) 395-414.

Rudolf of Fulda, Vita Leobae abbatissae Biscofesheimensis auctore Rudolfo Fuldensi, ed. Georg Waitz, MGH SS 15,1 (Hannover, 1887) 118-31.

Scheil, Andrew P., The Footsteps of Israel: Understanding Jews in Anglo-Saxon England (Ann Arbor, 2004).

Scior, Volker, Stimme, Schrift und Performanz: `Übertragungen` und >Reproduktionen durch frühmittelalterliche Boten, in: Britta Bussmann, Albrecht Hausmann, Annelie Kreft and Cornelia Langmann (eds.), Übertragungen: Formen und Konzepte von Reproduktion in Mittelalter und Früher Neuzeit (Berlin, 2005).

Smith, Anthony D., Chosen Peoples: Sacred Sources of National Identity (Oxford, 2003).

Story, Joanna, Bede, Willibrord and the Letters of Pope Honorius I on the Genesis of the Archbishopric of York, The English Historical Review 127/527 (2012) 783-818. 
Talbot, Charles Hugh, The Anglo-Saxon Missionaries in Germany: Being the Lives of SS. Willibrord, Boniface, Sturm, Leoba, and Lebuin, Together with the Hodoeporicon of St. Willibald and a Selection from the Correspondence of St. Boniface (London, 1954).

Thacker, Alan, Gallic or Greek? Archbishops in England from Theodore to Ecgberht, in: Paul Fouracre and David Ganz (eds.), Frankland: The Franks and the World of the Early Middle Ages. Essays in Honour of Dame Jinty Nelson (Manchester, 2008) 44-69.

Tugène, Georges, >L'histoire ecclésiastique du peuple anglais: Réflexions sur le particularisme et l'universalisme chez Bède, Recherches Augustiniennes 17 (1982) 129-72.

Vita Lebuini antiqua, ed. Adolf Hofmeister, MGH SS 30, 2 (Leipzig, 1934).

Vollrath, Hanna, Die Synoden Englands bis 1066 (Paderborn, 1985).

Wallace-Hadrill, J.M., Bede's Ecclesiastical History of the English People: A Historical Commentary (Oxford, 1988).

Wampach, Camille, Geschichte der Grundherrschaft Echternach im Frühmittelalter, vol. 1-2: Quellenband (Luxemburg, 1930).

Willibald, Vita Bonifatii auctore Willibaldo presbytero, ed. Wilhelm Levison, Vitae Sancti Bonifatii archiepiscopi moguntini, MGH Scriptores rerum Germanicarum 57 (Hannover, 1905) 1-58.

Wilson, Henry Austin (ed.), The Calendar of St Willibrord from MS Paris Lat. 10837: A Fascimile with Transcription, Introduction, and Notes, Henry Bradshaw Society 55 (London, 1918).

Wood, Ian, Who Are the Philistines? Bede's Reading of Old Testament Peoples, in: Clemens Gantner, Rosamond McKitterick, and Sven Meeder (eds.), The Resources of the Past in Early Medieval Europe (Cambridge, 2015) 172-87.

Wood, Ian N., The Missionary Life: Saints and the Evangelisation of Europe, 400-1050 (Harlow, 2001).

Wormald, Patrick, Bede, the bretwaldas and the Origins of the gens Anglorum, in: Stephen David Baxter (ed.), The Times of Bede: Studies in Early English Christian Society and its Historian (Malden, 2006), 106-134. First published in: Geoffrey Rowell (ed.), The English Religious Tradition and the Genius of Anglicanism (Nashville, 1992) 13-32.

Wormald, Patrick, Engla Lond: The Making of an Allegiance, Journal of Historical Sociology 7/1 (1994) 1-24.

Wormald, Patrick, The Venerable Bede and the >Church of the English', in: Stephen David Baxter (ed.), The Times of Bede: Studies in Early English Christian Society and its Historian (Malden, 2006) 207-28. First published in Journal of Historical Sociology 7/1 (1994) 1-24.

Yorke, Barbara, Anglo-Saxon Origin Legends, in: Julia Barrow, Andrew Wareham and Nicholas Brooks (eds.), Myth, Rulership, Church and Charters: Essays in Honour of Nicholas Brooks (Aldershot, 2008) 15-29.

Zacher, Samantha, Rewriting the Old Testament in Anglo-Saxon Verse: Becoming the Chosen People (London, 2013).

Ziegler, Michelle, The Ripon Connection? Willibrord, Wilfrid, and the Mission to Frisia, $\mathrm{He}$ roic Age 6 (2003). Retreived 31 March 2016: www.heroicage.org/issues/6/ziegler.html. 